\title{
CATCH-AND-RELEASE ICE FISHING WITH A MORMYSHKA FOR ROACH (Rutilus rutilus) AND EUROPEAN PERCH (Perca fluviatilis)
}

\author{
Tomasz K. Czarkowski ${ }^{1}$, Andrzej Kapusta ${ }^{2 *}$ \\ ${ }^{1}$ Warmia-Mazury Agricultural Advisory Centre (W-MODR) in Olsztyn, ul. Jagiellońska 37, 20-262 Olsztyn, \\ Poland \\ ${ }^{2}$ Department of Ichthyology, Hydrobiology and Aquatic Ecology, Inland Fisheries Institute, Olsztyn, Poland \\ *Corresponding Author, Email: a.kapusta@infish.com.pl
}

\section{ARTICLE INFO}

Received: 1 October 2019

Accepted: 31 October 2019

\section{Keywords:}

Ice-angling

Fisheries conservation

Hooking location

Landing efficiency

Winter

\section{ABSTRACT}

This study examined and described the basic parameters of the catchand-release angling of roach Rutilus rutilus and European perch Perca fluviatilis with the mormyshka technique. Catch efficiency, the size of the fish caught, the time required to unhook the fish and the total time during which the fish were handled, hooking location, the occurrence of injury and initial hooking mortality were determined. The study indicates that the mormyshka technique is an effective way to catch roach and European perch when ice fishing. The efficiency of the catches and landings was similar for barbed and barbless hooks. The mormyshka technique also proved to be safe for the fish during catch-and-release fishing. The decided majority of fish were hooked shallowly on the upper jaw, which is a safe location, and injury occurred rarely regardless of the hook type. Generally unhooking the fish from the mormyshka hook was seamless and fish handling was brief. Additionally, when roach were caught with barbless hooks, unhooking time and handling was shorter than it was with barbed hooks. No initial hooking mortality was observed in roach, while it occurred in only two specimens of European perch.

\section{How to Cite}

Czarkowski, K. T., Kapusta, A. (2019): Catch-and-release ice fishing with a mormyshka for roach (Rutilus rutilus) and european perch (Perca fluviatilis). Croatian Journal of Fisheries, 77, 235-242. DOI: 10.2478/cjf-2019-0017. 


\section{INTRODUCTION}

The popularity of different fishing techniques used in recreational angling varies and depends on many factors. Once such factor is climate conditions, especially when air temperatures are below freezing, which is the condition necessary for ice formation. The formation of ice cover is also associated with winter recreational angling activities and the popularity of particular fishing techniques that are used in northern countries and Central and Eastern Europe and in North America (Nuttall et al., 2004; Lehtonen, 2008; Wiśniewolski et al., 2009; Twardek et al., 2018). One of the specific, traditional fishing techniques used in Northern and Eastern Europe is ice fishing with a so-called mormyshka, which is a combination of artificiallive bait rig (Kekäläinen et al., 2014).

Anglers from Central and Eastern European countries fish two species of fish with particular frequency: roach Rutilus rutilus and European perch Perca fluviatilis. In Poland, they comprise together $41.7 \%$ of the biomass of all fish caught annually by recreational angling (Wołos et al., 2015). Both roach and European perch are also the most frequently caught species in winter during ice fishing, and together they may account for as much as $35.6 \%$ of the biomass of fish caught (Wiśniewolski et al., 2009). These species are also caught by recreational anglers in other European countries (Smith, 2002; Heerman et al., 2013). Additionally, European perch is a species that is caught with particular frequency during recreational ice fishing in Finland (Vainikka et al., 2012; Härkönen et al., 2016).

The efficiency and selectivity and the degree of fish injury and mortality in catch-and-release recreational angling depends on many factors. Hook type and size (Cook et al., 2005; Rapp et al., 2008; Patterson et al., 2012; Ateşşahin et al., 2015) and bait type and size (Arlinghaus et al. 2008; Garner et al., 2016) all significantly impact the efficiency and selectivity of recreational angling catches. The hooking location on the fish and any resulting injury, including bleeding (Meka, 2004; Rapp et al., 2008; Stålhammar et al., 2014), and the time required to unhook the fish and the total handling time (Cooke et al., 2001; Arlinghaus et al., 2008) can also impact parameters associated with fish condition and mortality. Some of these publications focus on the most popular freshwater species that are caught by catch-and-release recreational angling, i.e. rainbow trout Oncorhynchus mykiss (Meka, 2004), common carp Cyprinus carpio (Rapp et al., 2008) and northern pike Esox lucius (Pullen et al., 2017). However, to date no work has been published on the impact that catch-and-release angling has on roach and European perch caught with mormyshka micro-bait during recreational ice fishing. This provided the motivation to undertake the current study, the aim of which was to determine the basic catch parameters of catch-and-release ice fishing for roach and European perch using the mormyshka technique.

\section{MATERIALS AND METHODS}

Ice fishing was conducted in lakes Sarąg and Serwent between 25 January and 16 February 2017. Both lakes are located in northeastern Poland in the Masurian Lake District. Lake Sarąg has a surface area of $1.81 \mathrm{~km}^{2}$, and that of Lake Serwent is $2.435 \mathrm{~km}^{2}$. Both lakes are eutrophic (Choiński, 2006). Before beginning fishing, holes $12 \mathrm{~cm}$ in diameter were bored through the ice to permit deploying the fishing gear. Simultaneously, larger holes measuring approximately $50 \mathrm{~cm}$ in diameter were bored into the ice and net-holding cages were installed to hold the fish caught for a brief period. The net cages were cylindrical with a length of $300 \mathrm{~cm}$, a diameter of $50 \mathrm{~cm}$ and a mesh size of $6 \mathrm{~mm}$.

Fishing was done from the ice using standard gear for ice fishing with the mormyshka technique. The gear comprised a balalaika rod $30 \mathrm{~cm}$ in length with a built-in reel (Lowisko, Bałałajka Sport). Fishing line with a diameter of $0.09 \mathrm{~mm}$ (Fiume Super Competition) was wound on the reel. The strike indicator was a thin band of elastic plastic fastened to the rod. Mormyshka micro-bait was fastened to the end of the line (Kekäläinen et al., 2014). This bait is constructed similarly to a jig, but it is decidedly smaller. It has heavy head made of tungsten with a small hole for fastening the line and a permanent single hook positioned horizontally. Two similarly shaped mormyshkas (Lowisko, Dyskoteka) were used for the study catches, barbed J-type and barbless J-type. Because the mormyshka technique is a classic example of using combined artificial-live bait, each hook was also loaded with live bait with larval chironomids and maggots. To ensure that results were comparable, fishing was performed by an experienced angler (Rapp et al., 2008). The bait was deployed near the bottom and the depth of the fishing grounds in Lake Sarąg was $7.3 \mathrm{~m}$, while in Lake Serwent it was $7.1 \mathrm{~m}$.

All the fish were counted and measured (total length \pm 1 $\mathrm{mm}$ ). This data was used to describe the catch efficiency, which was expressed as catch per unit effort (CPUE), indicating the number of fish caught in one hour with one rod by the angler (individuals per person-hour). The fish that were hooked but that freed themselves off the hook during landing were also recorded. Since at the fishing grounds studied by-catch of other species was generally not noted, it was highly probable that the fish that fed off the hooks during landing belonged to the same species. This is how landing efficiency was determined, which was expressed as the percentage share of fish (\%) that, after hooking, were successfully landed (Prince et al., 2002; High and Meyer, 2014; Czarkowski and Kapusta, 2019). After landing, the hooking location of each fish was recorded. The locations penetrated by hooks were qualified as follows: upper jaw, lower jaw, corner of the mouth, palate, esophagus, external location (Rapp et al., 2008; Garner et al., 2016). The hooking location was recorded as either 
deeply hooked (in the esophagus or palate) or shallowly hooked (jaw, corner of mouth, external location), based on the point of hook entry. The occurrences of injury and/ or bleeding were also recorded. The time required for hook removal and the total time during which the fish were handled were also measured $( \pm 0.1 \mathrm{~s})$. After these manipulations, the fish were placed into holding cages in the water and it was determined whether initial hooking mortality occurred. The fish were observed to confirm that they were swimming normally, did not lose their equilibrium and were exhibiting opercular movements. Difficulty submerging beneath the ice was described as the occurrence of barotrauma. Subsequently, after four hours of holding in the cages, short-term mortality was determined by observing the fish to verify if they were still alive, swimming normally without a loss of equilibrium and were exhibiting opercular movements, the living fish were released. Arlinghaus et al. (2008) applied similar procedures arguing that short-term holding was dictated by the apprehension that crowding in cages or pens over long holding and observation periods artificially increases initial hooking mortality indexes, and by the assumption that variables determining initial hooking mortality also impact total hooking mortality. This approach was also dictated by air temperatures that were below freezing.

Two-way analysis of variance (ANOVA) was used to test for differences in hook removal times of the roach and European perch caught and among hook type. Dependent variables were analyzed for normal distribution (Kolmogorov-Smirnov test) and homogeneity of variances (Levene's test). The Tukey test was used for post hoc analyses. The catch efficiency of both species was expressed as CPUE, while mean handling time was tested with the Mann-Whitney $U$ test. The frequency of injury depending on hook type (barbed-barbless) and the length distribution of the fish caught were tested with the $\mathrm{Chi}^{2}$ test. The null hypothesis was that the distribution of injuries was identical regardless of hook type. The dependence between the time it took to unhook fish and their handling was described using the Pearson correlation. The statistical analyses were performed using Statistica 12 (StatSoft Inc., USA).

\section{RESULTS}

During the study, a total of 288 fish were caught, including 157 European perch and 131 roach. The mean ice fishing catch efficiency with mormyshkas was 14.4 fish per person-hour (Table 1). Average CPUE for roach was 16.4 $\mathrm{fish} / \mathrm{h}$, and for European perch it was $13.6 \mathrm{fish} / \mathrm{h}$ (Table 1). Additionally, no statistically significant differences in CPUE was noted with regard to the type of hook used (barbless or barbed) $(U=7.50, P=0.88)$. The mean total length of the roach caught was $155 \mathrm{~mm}$, while that of European perch was similar at $151 \mathrm{~mm}$ (Table 1). The fishes captured by each of the two mormyshka types had similar total lengths (respectively roach: $Z=1.84, P=0.06$, European perch: $Z=0.42, P=0.67$ ).

Hook type had no effect on the incidence of deep-hooking location (Table 1). The average deep-hooking rates were almost three times larger for European perch than for roach. Fish captured using the mormyshka (both barbed and unbarbed) were more frequently hooked in the upper jaw (Table 2).

Hooking location did not vary between the barbed and barbless catch of roach $\left(\mathrm{Chi}^{2}=3.66, \mathrm{df}=5, P=0.60\right)$, and European perch $\left(\mathrm{Chi}^{2}=7.48, \mathrm{df}=5, P=0.19\right)$. The injuries noted were not frequent; slight abrasions on the upper jaw were noted in $5.1 \%$ of European perch and $4.6 \%$ of roach. Slight bleeding was noted in only one European perch. More injuries to the mouth were noted with barbed hooks (6.9\%) than with barbless hooks (2.8\%). One case of bleeding was noted with a barbed hook. Only in two roaches it was necessary to use tools to remove hooks.

The mean time required to unhook fish was short at $1.8 \mathrm{~s}$. Hook removal times differed among species $(F=1.71, \mathrm{df}=$ $1,280, P>0.05)$; however, Tukey's test showed that there was only a significant difference between roaches caught on barbed and unbarbed mormyshka $(P=0.01)$. Hook removal from roach captured on barbed mormyshka took almost three times longer than the barbless mormyshka (respectively $2.5 \pm 4.08 \mathrm{~s}$, and $0.9 \pm 3.87 \mathrm{~s}$ ). Barbless mormyshka European perch catch averaged $1.6 \pm 1.05 \mathrm{~s}$ to remove the hook, and the barbed mormyshka catch took the most time $(2.3 \pm 1.82 \mathrm{~s})$.

Table 1. Ice fishing results expressed as CPUE (fish per angler per hour), mean TL, percentage deep-hooking and landing efficiency produced by different hook treatments

\begin{tabular}{|c|c|c|c|c|}
\hline \multirow{2}{*}{ Parameters } & \multicolumn{2}{|c|}{ European perch } & \multicolumn{2}{|c|}{ Roach } \\
\hline & Barbed hook & Barbless hook & Barbed hook & Barbless hook \\
\hline $\mathrm{TL}(\mathrm{mm})$ & $152.5 \pm 3.11$ & $150.7 \pm 5.19$ & $157.7 \pm 2.99$ & $153.2 \pm 3.59$ \\
\hline CPUE & $14.0 \pm 3.46$ & $13.0 \pm 4.24$ & $16.5 \pm 3.31$ & $16.2 \pm 2.06$ \\
\hline Landing efficiency (\%) & $82.5 \pm 17.5$ & $87.8 \pm 9.61$ & $91.5 \pm 3.24$ & $90.3 \pm 4.84$ \\
\hline Deep hooking (\%) & $8.6 \pm 8.28$ & $8.2 \pm 2.45$ & $3.1 \pm 3.61$ & $3.1 \pm 6.25$ \\
\hline
\end{tabular}


Table 2. Percentage of European perch and roach hooked in different anatomical hooking locations by barbed and barbless mormyshka

\begin{tabular}{|c|c|c|c|c|}
\hline \multirow{2}{*}{ Parameters } & \multicolumn{2}{|c|}{ European perch } & \multicolumn{2}{|c|}{ Roach } \\
\hline & Barbed hook & Barbless hook & Barbed hook & Barbless hook \\
\hline Upper jaw & $84.7 \pm 5.58$ & $81.8 \pm 15.23$ & $92.2 \pm 3.35$ & $92.4 \pm 7.94$ \\
\hline Lower jaw & $2.8 \pm 5.56$ & $0.8 \pm 1.67$ & - & $1.3 \pm 2.63$ \\
\hline Corner of the mouth & $3.9 \pm 4.88$ & $6.7 \pm 9.43$ & $1.2 \pm 2.38$ & $1.6 \pm 3.12$ \\
\hline Esophagus & $1.5 \pm 2.94$ & - & - & - \\
\hline Palate & $7.1 \pm 6.46$ & $10.7 \pm 6.56$ & $3.1 \pm 3.61$ & $3.1 \pm 6.2$ \\
\hline External & - & - & $3.5 \pm 4.07$ & $1.6 \pm 3.12$ \\
\hline
\end{tabular}

Table 3. Mean \pm SD of unhooking time (s) relative to hook type and anatomical hooking locations for ice-fished European perch and roach

\begin{tabular}{|c|c|c|c|c|c|c|}
\hline Parameters & Upper jaw & Lower jaw & Corner of the mouth & Esophagus & Palate & External \\
\hline \multicolumn{7}{|l|}{ European perch } \\
\hline Barbed hook & $2.1 \pm 1.53$ & $5.5 \pm 2.90$ & $2.1 \pm 0.86$ & 10.2 & $2.6 \pm 1.11$ & - \\
\hline Barbless hook & $1.5 \pm 0.86$ & 6.5 & $1.5 \pm 0.89$ & $0.0 \pm 0.00$ & $1.8 \pm 1.14$ & - \\
\hline Total & $1.8 \pm 1.27$ & $5.9 \pm 2.12$ & $1.8 \pm 0.86$ & 10.2 & $2.2 \pm 1.14$ & - \\
\hline \multicolumn{7}{|l|}{ Roach } \\
\hline Barbed hook & $2.0 \pm 1.30$ & - & 1.0 & - & $17.6 \pm 21.7$ & $4.2 \pm 5.30$ \\
\hline Barbless hook & $0.4 \pm 0.31$ & 0.3 & 0.7 & - & $16.5 \pm 21.14$ & 0.2 \\
\hline Total & $1.2 \pm 1.24$ & 0.3 & $0.8 \pm 0.21$ & - & $17.1 \pm 17.5$ & $2.9 \pm 4.42$ \\
\hline
\end{tabular}

Handling time was correlated with the time required to unhook roach $(r=0.62, P<0.05)$, but this dependence was not noted in European perch ( $r=0.14 P>0.05)$. Overall, the mean handling time for European perch was $32.4 \mathrm{~s}$, which was slightly longer for barbed hooks than for barbless hooks at $34.3 \mathrm{~s}$ and $30.3 \mathrm{~s}$, respectively $(Z=1.71$, $P=0.09)$. Similarly, the mean handling time for roach was $26.3 \mathrm{~s}$, which was slightly longer for barbed hooks than for barbless hooks at $27.4 \mathrm{~s}$ and $25.2 \mathrm{~s}$, respectively $(Z=$ 1.23, $P=0.22$ ).

Fishing with mormyshkas did not cause initial hooking mortality. Nor was short-term mortality observed after holding roach for $4 \mathrm{~h}$ in cages; however, in the case of European perch this type of mortality occurred in just two individuals. Both cases were associated with the use of rigs with barbed hooks. Additionally, barotrauma was confirmed in four European perch, which was evidenced by the fish having difficulty submerging in the cage, but these symptoms subsided during the four-hour holding period.

\section{DISCUSSION}

Ice fishing is characterized by the ease with which anglers can access sites where fish are located and the precision with which they can deliver bait to these locations. In the current study, roach CPUE was 16.4 individuals per personhour, while for European perch it was 13.1 individuals per person-hour. Smith (2002) reports that during pole fishing roach CPUE was 1.9 fish/h in fall and 8.7 fish/h in early spring. Heermann et al. (2013) report that the mean CPUE for European perch in summer months did not exceed 2 individuals per person-hour regardless of whether artificial or natural bait was used. In ice fishing catches of European perch, Vainikka et al. (2012) report a CPUE of 2.6 to 24.7 individuals per person-hour at a mean of 11.9 individuals per person-hour, which is similar to the results of the current study, but these authors used different techniques from the mormyshka.

In Central and Eastern Europe, barbless hooks are not common and circle-hooks are even less known. The main 
type of hook used remains the conventional barbed J-hook. Cooke and Suski (2004) demonstrated that for a new hook to gain acceptance among anglers, it must be at least as efficient as conventional hooks; they also add that the overall efficiency of catches has, among other factors, a great impact on landing efficiency. The study by Alós et al. (2008) indicates that barbed hooks are more efficient than barbless hooks. Meka (2004) also confirms that barbed hooks are more efficient. Our study indicates that when ice fishing for roach and European perch using mormyshkas, the hook type was inconsequential and had no significant impact on the level or efficiency of the catches. High landing efficiency when using barbless hooks in ice fishing probably stems from the fact that landing is relatively quick and is basically performed vertically, which prevents slackness in the line. In this instance, the barb on a hook loses its purpose, since it is meant, among other things, to prevent the hook from sliding out of fish tissue when the line is slack.

Hooking location is an important factor that has a considerable impact on other parameters associated with catch-and-release recreational angling, including with post-release mortality (DuBois et al., 1994; Lewin et al., 2006; Keith and Bruesewitz, 2007). Arlinghaus et al. (2008) divided hooking location in pike into those that are critical and those that are non-critical. The latter includes the upper and lower jaws and external locations, while the former include the gills and the esophagus (Arlinghaus et al., 2008). Garner et al. (2016) made similar differentiations with regard to European perch and designated additionally that deep hooking in the gills and esophagus are dangerous. In the current study, the decisive majority of fish were hooked in the upper jaw. It is apparent that this is one of the safest places to hook a fish and that it is relatively easy to remove a hook from this location. Other hooking locations were much rarer. It is probable that the frequent hooking on the upper jaw in the current study was associated with the technique and the specific mormyshka bait used. The bend in a mormyshka hook is directed upward and the tip of the hook is nearly horizontal with regard to the line, all of which predisposes hooking fish in the upper jaw. One can say that this construction and the results of present study permit forming the conclusion that the technique of angling with mormyshkas is fairly safe for fish caught in catch-and-release angling. In our study, over $90 \%$ of the roach and over $80 \%$ of the perch were hooked in the upper jaw. We also did not note any deep hooking of roach and did note isolated accidental deep hooking of perch. In the summer, when using other fishing methods, critical hooking locations can occur more frequently (Czarkowski and Kapusta, 2019).

One of the main problems of catch-and-release recreational angling is injury caused by hooks (Muoneke and Childress, 1994; Bartholomew and Bohnsack, 2005). Bleeding tissue injuries can be especially dangerous for fish (Arlinghaus et al., 2008). In carp catches, bleeding was conformed in $56 \%$ of fish caught with larger hooks, while $53 \%$ of fish had injured mouth tissues (Rapp et al., 2008). Present study confirmed that fishing with mormyshkas is safe since there was only one case of bleeding (in a European perch), and other injuries that were noted were infrequent; slight tears to the upper jaw (without bleeding) were noted in $5.1 \%$ of European perch and $4.6 \%$ of roach.

The next parameter that impacts fish mortality and condition is handling time and one of the most important elements of this is the time required to remove hooks (Cooke et al., 2001; Brownscombe et al., 2017). In this study, in which small fish were caught, the mean time required to unhook the fish was very short and was only a few seconds, which is decisively shorter than the time required to unhook larger fish, such as rainbow trout (Meka, 2004) or pike (Arlinghaus et al., 2008), which usually requires up to $30 \mathrm{~s}$. Simultaneously, it is widely known that a hook type can impact unhooking time and that barbed hooks require more time to be removed (Meka, 2004). This observation has been confirmed in roach, but not in European perch. This likely stemmed from the significant differences in the mouth build of these two species, because cyprinid mouths are more flexible with thicker flesh, which is why barbed hooks become more firmly embedded in the tissues.

No instances of initial hooking mortality were observed in roach, but two cases were noted in European perch, both of which were associated with barbed hooks, and one was linked with the fish having swallowed the bait deeply. As is widely known, initial hooking mortality can underestimate total hooking mortality (Wilde, 1998). However, it is also widely known that initial hooking mortality has a strong impact on total hooking mortality (Arlinghaus et al., 2008). Such low initial hooking mortality as recorded in the present study could lead to the conclusion that releasing small roach and European perch caught during ice fishing with mormyshkas could be safe and effective. One can conclude that the mormyshka technique is effective for catching small roach and European perch. In addition to its high efficiency, this technique also appears to be relatively safe for fish during catch-and-release fishing. The decided majority of fish were hooked shallowly in the upper jaw, which is a very safe location, and tissue injuries occurred very infrequently regardless of the type of hook. Unhooking mormyshka hooks was seamless and the time required to do this was very short.

The catch-and-release strategy allows to maintain a constant level and quality of catches along with the simultaneous increase in fishing effort and is becoming more and more popular not only in highly developed countries (Freire et al., 2012; Danylchuk et al., 2018). Polish anglers also more and more often declare their willingness to release caught fish, because the food purpose of fishing becomes less important. However, most anglers are convinced that all fish caught in ice in winter must be taken away, as they do not survive. Our 
research indicates that it may be different. Furthermore, in Poland, minimum landing sizes of $150 \mathrm{~mm}$ or $180 \mathrm{~mm}$ are in force for European perch at some fishing grounds and smaller fish must be released. Our study confirmed that releasing such small fish caught in winter with the mormyshka technique is relatively safe.

\section{ACKNOWLEDGMENTS}

We thank Bartosz Czarnecki for his invaluable assistance with this project. The research was funded under statutory research topic S-009 that is financed by the Inland Fisheries Institute in Olsztyn. Catch and release angling in Poland is not subject to approval of equivalent animal ethics committee, however AK has personal license to carry out regulated procedures on living animals (No. 3520/2016).

\section{SAŽETAK}

\section{RIBOLOV BODORKE (Rutilus rutilus) I EUROPSK- OG GRGEČA (Perca fluviatilis) POD LEDOM UZ POMOĆ MORMIŠKE (MORMYSHKA) S RI- BOLOVNOM TEHNIKOM „ULOVI I PUSTI”}

Ovim istraživanjem se ispitalo i opisalo osnovne pokazatelje ribolova ispod leda bodorke Rutilus rutilus i europskog grgeča Perca fluviatilis uz pomoć mormiške (mormyska) ribolovnom tehnikom "ulovi i pusti“. Određena je učinkovitost ulova, veličina ulovljene ribe, vrijeme potrebno za otkačivanje ribe $s$ udice, ukupno vrijeme rukovanja s ribom, mjesto kvačenja udice, pojava ozljeda i smrtnost. Istraživanje pokazuje da je tehnika mormyska efikasan način ribolova europskog grgeča i bodorke ispod leda. Učinkovitost ulova i podizanja ribe bila je slična za udicu s kukom i bez nje. Također, tehnika mormyshka se pokazala sigurnom za ribe tijekom ribolova „ulovi i pusti“. Većina ulovljenih riba bila je plitko zakačena na gornju vilicu, što se smatra sigurnim mjestom kvačenja udice, a ozljede su bile rijetko prisutne bez obzira na vrstu udice. Općenito, otkačivanje ribe s mormyshka kuke se izvodilo besprijekorno, a rukovanje ribom je bilo vremenski kratko. Dodatno, pri ulovu bodorke, vrijeme otkvačivanja i rukovanja ribe kod udica bez kuke je bilo kraće nego kod udica s kukom. Kod bodorke nije zabilježena smrtnost uzrokovana kukom dok je bila prisutna kod dva primjerka europskog grgeča.

Ključne riječi: Ribolov pod ledom, očuvanje ribarstva, mjesto kvačenja udice, učinkovitost podizanja ribe, zima

\section{REFERENCES}

Alós, J., M., Palmer, Grau A. M., Deudero, S. (2008): Effects of hook size and barbless hooks on hooking injury, catch per unit effort, and fish size in a mixed-species recreational fishery in the western Mediterranean Sea. ICES Journal of Marine Science, 65, 899-905.

Arlinghaus, R., Klefoth, T., Kobler, A., Cooke, S. J. (2008): Size selectivity, injury, handling time, and determinants of initial hooking mortality in recreational angling for northern pike: the influence of type and size of bait. North American Journal of Fisheries Management, 28, 123-134.

Ateşşahin, T., Duman, E., Cilbiz, M. (2015): Selectivity and Catch Efficiency of Three Spinner Hook Sizes in Angling for Rainbow Trout (Oncorhynchus mykiss Walbaum, 1792) in Karakaya Dam Lake (Eastern Turkey). Turkish Journal of Fisheries and Aquatic Sciences, 15, 851-859.

Bartholomew, A., Bohnsack, J. A. (2005): A review of catchand-release angling mortality with implications for notake reserves. Reviews in Fish Biology and Fisheries, 15, 129-154.

Brownscombe, J. W., Danylchuk, A. J., Chapman, J. M., Gutowsky, L. F. G., Cooke, S. J. (2017): Best practices for catch-and-release recreational fisheries - angling tools and tactics. Fisheries Research, 186, 693-705.

Campbell, M. D., Pollack, A. G., Driggers, W. B., Hoffmayer, E. R. (2014): Estimation of Hook Selectivity of Red Snapper and Vermilion Snapper from FisheryIndependent Surveys of Natural Reefs in the Northern Gulf of Mexico. Marine and Coastal Fisheries, 6, 260273.

Choiński, A. (2006): Catalog of Polish Lakes. Wyd. Nauk. UAM, Poznań (in Polish).

Cooke, S. J., Suski C. D. (2004): Are circle hooks an effective tool for conserving marine and freshwater recreational catch-and-release fisheries? Aquatic Conservation: Marine and Freshwater Ecosystems, 14, 299-326.

Cooke, S. J., Philipp, D. P., Dunmall, K. M., Schreer, J. F. (2001): The influence of terminal tackle on injury, handling time, and cardiac disturbance of rock bass. North American Journal of Fisheries Management, 21, 333-342.

Cooke, S. J., Barthel, B. L., Suski, C. D., Siepker, M. J., Philipp, D. P. (2005): Influence of circle hook size on hooking efficiency, injury, and size selectivity of bluegill with comments on circle hook conservation benefits in recreational fisheries. North American Journal of Fisheries Management, 25, 211-219.

Czarkowski T. K., Kapusta A. (2019): The impact of angling experience on the efficiency of float fishing using different hook types. Fisheries \& Aquatic Life, 27, 4146. 
Danylchuk, A. J., Clark Danylchuk, S., Kosiarski, A., Cooke, S. J, Huskey, B. (2018): Keepemwet Fishing-An emerging social brand for disseminating best practices for catch-and-release in recreational fisheries. Fisheries Research, 205, 52-56.

DuBois, R. B., Margenau, T. L., Stewart, R. S., Cunningham, P. K., Rasmussen, R. W. (1994): Hooking mortality of northern pike angled through ice. North American Journal of Fisheries Management, 14, 769-775.

Freire, K. M., Machado, M. L., Crepaldi, D. (2012): Overview of inland recreational fisheries in Brazil. Fisheries, 37, 484-494.

Garner, S. B., Dahl, K. A., Patterson, W. F. III. (2016): Hook performance and selectivity of European perch, Perca fluviatilis (Linnaeus, 1758) in the Åland Archipelago, Finland. Journal of Applied Ichthyology, 32, 1065-1071.

Härkönen, L., Hyvärinen, P., Petri, T., Niemelä, P. T., Vainikka, A. (2016): Behavioural variation in European perch populations with respect to relative catchability. Acta Ethologica, 19, 21-31.

Heermann, L., Emmrich, M., Heynen, M., Dorow, M., König, U., Borcherding, J., Arlinghaus, R. (2013): Explaining recreational angling catch rates of European perch, Perca fluviatilis: the role of natural and fishingrelated environmental factors. Fisheries Management and Ecology, 20, 187-200.

High, B., Meyer, K. A. (2014): Hooking mortality and landing success using baited circle hooks compared to conventional hook types for stream-dwelling trout. Northwest Science, 88, 11-22.

Keith, A. R., Bruesewitz, R. E. (2007): Factors influencing the hooking mortality of walleyes caught by recreational anglers on Mille Lacs, Minnesota. North American Journal of Fisheries Management 27, 443-452.

Kekäläinen, J., Podgorniak, T., Puolakka, T., Hyvärinen, P., Vainikka, A. (2014): Individually assessed boldness predicts Perca fluviatilis behaviour in shoals, but is not associated with the capture order or angling method. Journal of Fish Biology, 85, 1603-1616.

Lehtonen, H. (2008): Potential effects of global warming on northern European freshwater fish and fisheries. Fisheries Management and Ecology, 3, 59-71.

Lewin, W. C., Arlinghaus, R., Mehner, T. (2006): Documented and potential biological impacts of recreational fishing: insights for management and conservation. Reviews in Fisheries Science, 14, 305-367.

Meka, J. M. (2004): The influence of hook type, angler experience, and fish size on injury rates and the duration of capture in an Alaskan catch-and-release rainbow trout fishery. North American Journal of Fisheries Management 24, 1309-1321.
Muoneke, M.I., Childress, W.M. (1994): Hooking mortality: a review for recreational fisheries. Reviews in Fisheries Science, 2, 123-156.

Nuttall, M., Berkes, F., Forbes, B., Kofinas, G., Vlassova, T, Wenzel, G. (2004): Hunting, herding, fishing and gathering: indigenous peoples and renewable resource use in the Arctic. pp. 649-690. In: Symon, C., Arris, L., Heal, B. (eds), Arctic climate impact assessment. Cambridge University Press, Cambridge.

Patterson, W. F. III, Porch, C. E., Tarnecki, J. H., Strelcheck, A. J. (2012): Effect of circle hook size on reef fish catch rates, species composition, and selectivity in the northern Gulf of Mexico recreational fishery. Bulletin of Marine Science, 88, 647-665.

Prince, E. D., Ortiz, M., Venizelos, A. (2002): A comparison of circle hook and "J" hook performance in recreational catch-and-release fisheries for billfish. American Fisheries Society Symposium, 30, 66-79.

Pullen, C. E., Hayes, K., O'Connor, C. M., Arlinghaus, R., Suski, C. D., Midwood, J. D., Cooke S. J. (2017): Consequences of oral lure retention on the physiology and behaviour of adult northern pike (Esox lucius L.). Fisheries Research, 186, 601-611.

Rapp, T., Cooke, S. J., Arlinghaus, R. (2008): Exploitation of specialised fisheries resources: The importance of hook size in recreational angling for large common carp (Cyprinus carpio L.). Fisheries Research, 94, 79-83.

Smith, P. A. (2002): The relationship between stock and catch and the effect of bait on catch as determined for a UK recreational catch and release fishery. Fisheries Management and Ecology, 9, 261-266.

Stålhammar, M., Linderfalk, R., Brönmark, C., Arlinghaus, R., Nilsson, P. A. (2012): The impact of catch-andrelease on the foraging behaviour of pike (Esox lucius) when released alone or into groups. Fisheries Research, 125-126, 51-56.

Twardek, W. M., Lennox, R. J., Lawrence, M. J., Logan, J. M., Szekeres, P., Cooke, S. J., Tremblay K., Morgan G. E., Danylchuk, A. J. (2018): The Postrelease Survival of Walleyes Following Ice-Angling on Lake Nipissing, Ontario. North American Journal of Fisheries Management, 38: 159-169.

Vainikka, A., Koskimäki, J., Niemelä, P.T., Kortet, R. (2012): Composition of the European perch (Perca fluviatilis) catches in ice fishing: Does capture order predict body size? Fisheries Research, 115-116, 24-30.

Wilde, G. R. (1998): Tournament-associated mortality in black bass. Fisheries, 23, 12-22.

Wiśniewolski, W., Wołos, A., Borzęcka, I. (2009): Assessing angling catches in dam reservoirs on the example of Zegrze Dam Reservoir. Archives of Polish Fisheries, 17, 211-220. 
Wołos, A., Draszkiewicz-Mioduszewska, H., Trella, M. (2015): Characteristics of recreational angling pressure and catches in a lake exploited by a fisheries enterprise in 2013. pp. 159-171. In: Mickiewicz, M., Wołos, A. (eds), Sustainable exploitation of fisheries resources and their status in 2014. Wydawnictwo IRS, Olsztyn, (in Polish). 